\title{
Challenges Facing Drug Utilization Research in the Latin American region
}

Maribel Sales, Daiici Sankyo Inc, USA, and University of Pennsylvania USA; Luciane Lopes, University of Sorocaba, Brazil; Brian Godman, Karolinska Institute, Stockholm, Sweden and Strathclyde Institute if Pharmacy and Biomedical Sciences, Strathclyde University, Glasgow, UK; Ilse Truter, Nelson Mandela University, Port Elizabeth, South Africa; Abraham Hartzema, University of Florida, Florida, USA; Bjorn Wettermark, Karolinska Institute, Stockholm, Sweden; Joseph Fadare, Ekiti State University, Nigeria; Johanita Burger, North West University, South Africa; Kwame Appenteng, Astellas Pharmaceuticals US Inc, USA; Macarius Donneyong, Ohio State University, USA; Ariel Arias, Health Canada, Canada; Daniel Ankrah, Korle Bu Teaching Hospital, Accra, Ghana; Olayinka Ogunleye, Lagos State University College of Medicine, Lagos, Nigeria; Martha Lubbe, North West University, South Africa; Laura Horne, Daiici Sankyo Inc, USA; Jorgelina Bernet, National University of Colorado, USA; Diana Gomez-Galicia, Autonomous National University of Mexico, Mexico; Miriam Estrada Garcia, University of San Carlos of Guatemala, Guatemala; Margaret Oluka, University of Nairobi, Nairobi, Kenya; Amos Massele, University of Botswana, Botswana; Luis Alesso, University of Cordoba, Cordoba, Spain; Raquel Herrera Comoglio, University of Cordoba, Cordoba, Spain; Elisangela da Cost Lima, Federal University of Rio de Janeiro, Brazil; Carmen Vilaseca, College of Biochemistry and Pharmacy; Ulf Bergman, Karolinska Institute, Sweden

(Accepted for publication Pharmacoepidemiology and Drug Safety)

Key Messages

1. Drug utilization research (DUR) has advanced considerably in developed countries. However, the advance in the Latin America has been slow, which might be associated with fewer resources dedicated to DUR, fragmented or not fully integrated healthcare systems with limited access to electronic health records, registries and computerized decision-support systems.

2. The availability of national data on DU in most countries of the Latin American region is scarce and fragmented and as consequence, decision-makers often have limited qualitative or quantitative information on drug consumption and use to make informed decisions, develop drug policies, establish educational programs or evaluate interventions.

3. In some Latin America countries, decision-makers may be unaware of the importance of DU data in the decision-making process, which has a negative impact not only on the distribution of resources but also on the development of DUR.

4. The limited information of DUR from the Latin America region indicates an increased in the use of medicines overall as well as inappropriate prescribing, dispensing and misuse of medicines leading to medication errors and antimicrobial resistance, polypharmacy, self-medication among others, which is attributed to multiple factors including increased 
life expectancy with the consequence of aging of the population, epidemiologic transition from infectious diseases to chronic diseases and increased medicalization of society.

5. The available information for DUR also pointed out some issues particularly those related to validity of information and data collection instruments, insufficient data on medication consumption from the public healthcare sector, fewer quantitative DU studies, lack of studies of some population such as pregnant women, pediatric population or other, or to consumers of a particular healthcare service, and limited focus for future DU interventions to patients with no involvement of health care provider.

\section{Abstract}

This document represents an initiative of the International Society of Pharmacoepidemiology (ISPE) in collaboration with the Latin American Drug Utilization Research Group (LatAmDURG), the Medicines Utilization Research in Africa (MURIA) group, and the Uppsala Monitoring Center, to identify the main challenges associated with drug utilization research (DUR) in the LatAm and African regions. Furthermore, some solutions to overcome those challenges are proposed to accelerate the development of DUR in these regions. As result of this initiative, four separate manuscripts will present the results focused on: 1) challenges facing DUR in the LatAm region; 2) challenges facing DUR in Africa; 3) potential solutions to overcome these challenges, and 4) guidance for researchers interested in carrying out DUR in these regions. This is the first manuscript, and it is related to the challenges identified in the drug utilization research area in the LatAm region. DU researchers in LatAm voluntarily participated in multiple discussions, contributed with local data and reviewed successive drafts and the final document.

\section{Introduction}

\section{Drug Utilization Research: Definitions, Value and Regional Challenges}

The World Health Organization (WHO) (1977) defined drug utilization (DU as the "marketing, distribution, prescription, and use of drugs in society, with special emphasis on the resulting medical, social, and economic consequences" $[1,2]$. This definition has evolved to emphasize the importance of qualitative studies, analytical observational research and interventions to improve the process of using medicines in society [1], and according to the European Drug Utilization Group (EuroDURG), DU is an "eclectic collection of descriptive and analytical methods for the quantification, the understanding and the evaluation of the processes of prescribing, dispensing and consumption of medicines, and for the testing of interventions to enhance the quality of these processes" $[3,4]$.

Drug utilization research (DUR) provides valuable information about the use of medicines among populations [5], which can offer insights into the effectiveness, efficiency and safety of medicines use $[6,7,8,9,10,11]$, help to set priorities for the rational allocation of healthcare budgets [12], 
and examine the impact of pharmaceutical policies, including policies to reduce self-purchasing of medicines (the purchase of medications outside the legal distribution channels) where pertinent $[13,14,15]$. Further, DUR forms the cornerstone of pharmaceutical policies promoting equitable access to, and the rational use ${ }^{1}$ of medicines across populations $[3,16]$. DUR is an essential part of pharmacoepidemiology as it describes the extent, nature and determinants of drug exposure [1], which can be associated with outcomes. For instance, results of a recent database study in the Brazilian general population described the use of cyclosporine or tacrolimus among patients who underwent kidney transplantation between January 1, 2000, and December 31, 2009, suggesting greater effectiveness for cyclosporin versus tacrolimus for continued survival of kidney grafts [17]. DUR may also provide a proxy of denominators in pharmacovigilance [3], as in the Gattas' study where the Instituto Butantan in Brazil used doses of triple influenza vaccine as denominator to estimate the incidence rates of adverse events following immunization [18].

Despite many advances in DUR methodologies, moving from merely descriptive studies to analytic studies with the inclusion of quality indicators, and lately drug use as indicators of the quality of the healthcare system, in some regions, such as Latin America (LatAm), these advances have been slow $[19,20,21]$. This region faces particular challenges because of fewer resources, and/or fragmented or not fully integrated healthcare systems with limited access to electronic health records, registries and computerized decision-support systems.

Consequently, national data on DU are scarce and fragmented in the LatAm region. Decisionmakers often have limited qualitative or quantitative information on drug consumption and use to make informed decisions, develop drug policies, establish educational programs or evaluate interventions $[22,23,24,25]$. Probably more critical is the fact that in some LatAm countries decision-makers may be unaware of the importance of DU data in the decision-making process $[26,27]$. Multiple groups have been formed to improve DUR around the world including the Latin American Drug Utilization Research Group (LatAm-DURG) [28], the Medicines Utilisation Research in Africa (MURIA) group [29], The Uppsala Monitoring Center [30], and the WHO through different WHO Collaborative Centers such as the WHO Collaborating Centre of Pharmacovigilance, the WHO International Working Group for Drug Statistics Methodology, WHO Collaborating Centre for Drug Utilization Research and Clinical Pharmacological Services, and the Pan American Health Organization (PAHO) [31].

This document represents an initiative of the International Society of Pharmacoepidemiology (ISPE) in collaboration with the LatAm-DURG, the MURIA group from Africa, and the Uppsala Monitoring Center, to address current concerns; and it reflects the efforts to accelerate the

\footnotetext{
${ }^{1}$ According to the WHO "Medicine use is rational (appropriate, proper, correct) when patients receive the appropriate medicines, in doses that meet their own individual requirements, for an adequate period of time, and at the lowest cost both to them and the community. Irrational (inappropriate, improper, incorrect) use of medicines is when one or more of these conditions is not met." [16].
} 
development of DUR in the LatAm region. Contributors to this project, some of whom are DU researchers in LatAm, voluntarily participated in multiple discussions, contributed with local data and reviewed successive drafts and the final document.

Findings from this project will be presented in four separate manuscripts, focusing on: 1) challenges facing DUR in the LatAm region; 2) challenges facing DUR in Africa; 3) potential solutions to overcome these challenges, and 4) guidance for researchers interested in carrying out DUR in these regions.

\section{The Latin American Region}

\section{Population}

The LatAm region is a diverse and densely populated region with nearly 646 million people, representing $9 \%$ of the global population in $2017[32,33]$. Approximately a quarter of the population are children under 15 years of age, and 17\% are young people aged between 15-29 years [1]. The overall life expectancy is approximately 75 years, and the proportion of the population aged 60 years and above is expected to double in the next three decades (from $12 \%$ in 2017 to $25 \%$ in 2050$)[32,34]$.

The LatAm region comprises 41 countries varying in size from $<100,000$ inhabitants to $>190$ million inhabitants. It is worth noting that Brazil and Mexico are among the ten largest countries in the world $[32,34]$. In the LatAm region, there are high levels of socioeconomic inequality, hosting 10 of the world's 15 countries with the largest gap between low- and high-income citizens $[35,36,37]$. The LatAm region is considered a net ${ }^{2}$ sender of international migrants to developed countries particularly the United States [34], and migration from country to country within the region [31], which might impact DU studies in places with high migration rates.

In the LatAm region, there are more than 800 different indigenous groups primarily concentrated in Bolivia, Guatemala, Peru, Ecuador and Mexico. Compared to the non-indigenous populations, these indigenous populations generally have a low literacy level, low socioeconomic status with high overall morbidity and mortality, particularly infant mortality and maternal mortality, and a higher incidence of infectious diseases. This has resulted in high health-care needs, particularly access to medications [38].

Access to education also remains a challenge in the LatAm region with important regional differences, and in some countries only $35 \%$ of young men and women are attending school [39]. In 2017, approximately 184 million people (30.2\% of the population) in the LatAm and Caribbean

\footnotetext{
${ }^{2}$ Difference between the number of immigrants and the number of emigrants for a given country or group of countries [32].
} 
regions lived below the poverty line, almost 62 million of whom lived in extreme poverty [32, 40]. The main spoken language in the LatAm region is Spanish followed by Portuguese, French and multiple native languages, factors that are important to consider in DUR, particularly in the design of surveys, educational programs or patient-focused interventions.

\section{Socioeconomic Situation}

The economic instability produced by financial crises and natural disasters in the LatAm region have hindered the progress of the region [41]. In some countries in the region, social and political instability affects both access to medical care and medicines as well as the use of medicines. Crime, violence, human and drug trafficking, possession of illegal drugs, substandard and counterfeit medicines might influence how people are using their medicines [42]. It is estimated that one quarter of the 600,000 global homicides occur in LatAm [43] with wide variation among countries [44]. Homicides in Central and South America are frequently linked to violence and organized criminal groups, which depends on the availability of weapons, use of psychoactive substances and/or alcohol consumption, factors that will also impact the use of medicines including drug-drug interactions [45]. Furthermore, there are high rates of injuries in the young population, being the leading cause of death among young and middle-aged men (15-59 years of age) [46]. Social inequality, unemployment, urban segregation, illicit drugs and alcohol use are factors associated with high violence in the region [47].

\section{Health and Healthcare}

In the LatAm region, there is also an epidemiological transition from communicable diseases to non-communicable diseases with wide variation among countries. Some LatAm countries have a high predominance of non-communicable diseases while others have a predominance of communicable diseases $[48,49]$. This explains the heterogeneous mortality trends in the region, where the double burden of communicable and non-communicable diseases is common with significant impact on the healthcare system $[50,51]$. Among communicable diseases, the most frequent diseases include cholera, vector-borne diseases (malaria, dengue, Zika, and chikungunya), neglected infectious diseases, vaccine-preventable diseases, communicable chronic diseases such as tuberculosis and leprosy, sexually transmitted diseases, and zoonoses such as rabies and leptospirosis [49]. In terms of chronic diseases, the most frequent diseases include cardiovascular diseases, diabetes, malignant neoplasms, and respiratory diseases, which cause four out of five deaths in the region $[50,52]$. Those chronic diseases are increasing because of the aging of the population, health behaviours influenced by globalization, with a subsequent increase in obesity and physical inactivity [53].

In terms of healthcare, most healthcare systems in the LatAm region are fragmented in their provision of services, an important factor in the estimation of national coverage. This also limits 
the collection of accurate information on the distribution and access to medicines [54]. Furthermore, not all populations have medical coverage especially the poorest people, those with geographical isolation, unemployed or with low education (social exclusion) [55]. To reduce inequalities in access to health services and outcomes, some LatAm countries have begun social sector reforms of their health systems focusing on expansion of universal health coverage [56]. For example, in Brazil [57], Costa Rica, and Mexico, the expansion of universal financial coverage of healthcare services, including medications, reduced catastrophic health expenditures among the poor $[58,59,60]$. It is estimated that the average expenditures for medicines represent approximately $35 \%$ of total health costs $[54,55]$, which can be increased up to $60 \%$ [3], and might be even higher among the non-insured population. This percentage of total health expenditure is almost two-fold higher than for instance in Canada (16\%) [61] and in high-income countries $(19.7 \%)$ [62].

Most countries from the LatAm region have two formal sectors, private and public [63], and an informal sector for the distribution of pharmaceuticals. The informal sector is an unregulated establishment with vendors operating without a license to sell medicines and, in rural areas the informal sector might be the prominent sector for the distribution of medicines. The private sector is licensed to dispense and/or commercialize medicines independent of government programs. The private sector usually has available consumption data collected by private market research organizations, such as IQVIA ${ }^{\mathrm{TM}}$ (previously known as QuintilesIMS). The public sector includes institutions under the direct control of the national health agencies (e.g. Ministry of Health), other governmental institutions, or faith-based organizations. The public sector has limited available data for DUR, and usually restricts the use of such data. In some countries like Mexico, the social security system collects data for internal purposes, with no access granted to researchers outside the institution. In Brazil, there is access to research institutions for drug utilisation data to help with DU research including burden of illness studies as well as effectiveness studies [6, 64, 65, $66,67]$. In addition, drug-related policies within a country often change from one government to the next one, and among agencies within the same country. Patients may procure medicines from one, two, all three or none of the sectors depending on the agency policies, their employment status or socioeconomic status, the availability of medicines in public pharmacies, distance to the healthcare facility and agreements between a public institution and private pharmacies [55, 68]. This situation represents a challenge when a researcher is interested in evaluating the use of medicines particularly for DU studies over time and among institutions even within the same country. This means that DU data on a single patient may not always be complete.

\section{Counterfeit and substandard medicines}

One important issue in the LatAm region is the trade of substandard and counterfeit medicines, which are medicines deliberately and fraudulently mislabelled with respect to their identity and/or source and might include products with the correct ingredients but fake packaging, with the wrong ingredients, without active ingredients or with insufficient active ingredients [69]. Counterfeiting of medicines has increased substantially in developing countries where the primary targets are 
antimicrobials commonly used in the treatment of life-threatening conditions such as malaria, tuberculosis (TB) and HIV/AIDS [70]. According to the Center for Medicine of the Public Interest in the United States of America, the worldwide sales of counterfeit medicines was around US\$ 75 billion in 2010 [71]. The counterfeit drugs market is a well-organized market that according to the WHO represents approximately $25 \%$ of the medicines consumed in developing countries [72, 73], probably because of the costs of legitimate medicines, the existence of high patient co-payments and weak legal controls [71]. Improved access programmes are starting in some countries to make quality medicines affordable to improve care especially in patients with chronic diseases, and this practice may grow.

Counterfeit medicine use is identified as one of the major causes of treatment failures and may lead to serious adverse events resulting in excessive mortality and morbidity; and it is a contributor in the development of drug resistant organisms [68]. Various factors have been associated with the increase of counterfeited medicines in developing countries include poverty, high cost of quality medicines, lack of an official supply chain, legislative lacunae, easy accessibility to computerised printing technology, ineffective law enforcement, and light penalties [74]. As response measures to the issue of counterfeiting, some Latin American governments have implemented new laws and regulatory systems aiming at data collection, raising awareness controlling medicines importation and exportation as well as regulating the circulation of ingredients and goods for making drugs [71]. In addition, the new regulations include the coordination of special programs among various stakeholders to monitor the quality of regulated products and services. Additional measures include stricter control of movement of goods at ports, airports and borders, to ensure the sanitary control of facilities, services and means of transportation, products' import and the protection of travelers' health. In the case of Brazil, products regulated by ANVISA (regulatory authority of Brazil) are subjected to authorizations at borders when entering Brazil and might be subjected to physical inspection. Some classes of medicines may require authorizations prior to their embarkation in the exporting country [75]. A recent study in Brazil found that most counterfeiting products were medicines for erectile dysfunction, and authors recommended that ANVISA train health professionals to identify fake medications, to include methods of traceability of medicines from the manufacturer to distribution and sale points. Further, if smuggled and unregistered medicines are sold at free fairs and clandestine drugstores, health authorities should have the infrastructure to identify them and release alerts quickly [76].

The lack of or insufficient number of quality control centers is a contributing problem in the LatAm region. Various studies have identified substandard local manufacturing quality or inadequate transportation and storage conditions in the supply chain, or both [77, 78]. However, there are now some initiatives trying to quantify drug quality problems in the LatAm region such as the South American Infectious Disease Initiative ("Iniciativa de Enfermedades Infecciosas en América del Sur") in Peru [79] or to improve the quality of medicines such as the Amazon Malaria Initiative. The South American Infectious Disease Initiative reported that 25\% of 62 analyzed medicines did 
not reach the approved specifications and 3\% of medicines had critical failures. As a consequence, a collaborative effort between some LatAm countries and the USP "Promoting the Quality of Medicine's (PQM)", resulted in the creation of the database "Medicines Quality Database (MQDB)" which houses data related to substandard and counterfeit medicines circulating in the LatAm and Caribbean region [80, 81]. Hopefully, this will help to reduce the problem in the future.

\section{Drug Utilization in LatAm}

Despite limited DUR in the LatAm region, available studies suggest an increased use of medicines overall as well as inappropriate use of medicines leading to medication errors and antimicrobial resistance. However, study design limitations with the existing DUR limit the possibility of generalization and brings to question the validity of the DU data [3, 82, 83, 84]. The overall use of medicines in the LatAm region accounts for up to $60 \%$ of total healthcare spending in some LatAm countries [3]. In May 2012, there was an estimated market size of approximately $\$ 66$ billion dollars and rising in the LatAm region [80]. The increase in the use of medicines is attributed to various factors including increased life expectancy with the consequence of aging of the population, epidemiologic transition from infectious diseases to chronic diseases and increased medicalization of society.

Despite this increase in the use of medicines, available DU data remain scarce and fragmented across the region [3], and data quality varies among studies. This result in limited monitoring of medication use and comparison across countries and ultimately hamper the rational use of medications [3, 26]. Drug utilization researchers should identify and acknowledge the strengths and weakneses of the sources of information. For example, if the Intercontinental Marketing Services (IMS) Health data are used, the investigator should clearly convey in the presentation of study resutls that the analyzed data covered only the private sector. Since IMS Health collects data mainly from wholesalers, it means that the information is related to medicines sold in the medicine supply system but not necessarily to the medicines used by patients. Interestingly, studies using IMS data in some countries are often not conducted by local researchers $[85,86]$. Other sources of data may include community and hospital pharmacies, prescribers and electronic medical records and do also require critical analysis to determine the representativeness of the population covered and the characteristics of the target population.

The lack of local data has forced decision-makers to extrapolate information from studies conducted in other countries and different cultural contexts, which represents a challenge in the interpretation of results for policy interventions in LatAm countries [87, 88, 89]. Although, there are some tools for drug policy-making and drug education programs, such as the information on DU standards that has pointed out gaps between research, therapeutic practice and population health needs, its use by decision-makers remains limited [90]. However, this is likely to change as the number of DU studies in LatAm countries grow. 
Although there are limited studies of DUR available in LatAm, those available studies have identified issues in relation to inappropriate prescribing, inappropriate dispensing and misuse of medicines, polypharmacy, self-medication [91], quality of medicine use [3, 92, 93, 94, 95, 96, 97, 98, 99, 100], antimicrobial resistance [101, 102, 103, 104, 105] and poor patient adherence [106]. For example, a population-based cross-sectional study in 1,254 individuals aged 60 years or older from Brazil found $28 \%$ of medicines potentially inappropriately used [107]. In Colombia, a study of medication errors using outpatient pharmacy services and national medication dispensing from Jan 2005 to Sep 2013 found a total of 14,873 medication errors where $\sim 16 \%$ reached the patient and $0.7 \%$ caused harm. Those errors occurred mainly in the administration, dispensing, transcription and interpretation of prescriptions [108]. In Mexico, a study determining the frequency of potential drug-drug and drug-disease interactions among 624 ambulatory patients over 50 years of age with non-malignant pain syndrome, showed that patients received was an average of $5.9+/-2.5$ prescribed medicines. About $80 \%$ of the patients had prescriptions implying one or more potential drug-drug interactions [109]. As mentioned, drug utilization studies in Brazil have questioned the continued preference of tacrolimus over cyclosporin to prevent rejections in kidney transplant patients as well as endorsed the limited use of less effective beta-interferon preparations for the treatment of multiple sclerosis $[17,110]$.

A literature review to identify methodological issues with DUR in LatAm found that only two systematic reviews of DU studies have been performed in these areas. The most frequent issues identified included: i) scarce number of DUR studies comparing cross-nationally data; ii) validity issues, particularly extrapolation bias, iii) insufficient availability of data on drug consumption from the public healthcare sector [92], iv) limited information on qualitative studies, v) lack of validation of data and/or data collection instruments, vi) studies of specific target population such as pregnant women, pediatric population or other, or to consumers of a particular healthcare service, and vii) limited focus for future DU interventions to patients with no involvement of health care providers [111] . These issues need to be addressed to enhance the use of DU studies especially policy and other studies to enhance the rational use of medicines in LatAm countries.

\section{Specific challenges facing DUR in LatAm}

The socioeconomic inequality throughout LatAm is one of the main challenges potentially impacting on DU studies in the region, as it impacts access to care in the region. As mentioned, there is a large income gap between the rich and poor, disparities of social determinants of health, and differences in the quality of public and private health sectors. Access to medical care is also an issue even in those countries with one payer system. As consequence, some patient groups are using litigation as a way to get access to healthcare services and medicines in the LatAm region [112]. Universal healthcare systems cannot guarantee that patients will receive all needed services, and in most cases, the right to healthcare is restricted to the provision of medical and hospital services [113]. Furthermore, the complexity in the provision of services has obligated some citizens to use judicial processes [114], to demand the "right of health" $[113,115,116,117,118$, 
$119,120,121]$, which has been reflected in the creation of training programs targeting judges and courts in Brazil, Argentina and Costa Rica [122].

Although some governments from the LatAm region have created programs to improve access to health services and to narrow the gap between the rich and the poor, inequalities still exist [21], particularly inequitable financing in the region [58]. Some countries such as Colombia and Mexico have used interventions to control the regulation of the healthcare market, the costs of provision, and the standardization and updating of health services plans, which includes updated interventions $[122,123,124,125]$. These are important factors to consider when planning a DUR in LatAm countries.

Another important challenge for this region is the organisation of healthcare systems and the extent of healthcare data available to help governments in the identification of emerging health needs coming from social and demographic transitions, or from outbreaks of emerging pathogens. This challenge has been recognized by international organizations such as the WHO particularly with the increase of antimicrobial resistance [126, 127], and some programs to increase microbial surveillance and antimicrobial resistance have been initiated in the LatAm region [126, 128].

Although 26 Latin American countries have adopted the essential drug list (a list of minimum medicine needs for a basic health-care system, listing the most efficacious, safe and cost-effective medicines for priority conditions published by the WHO $[129,130]$, which is frequently used by countries to help develop their own local lists of essential medicines, only a few countries update their essential drug list every two years [131]. In Brazil, the list of essential drugs has been reported to include discrepancies between the WHO recommendations and the drugs included in the Brazilian National Relation of Essential Medicines [132, 133, 134, 135, 136, 137], as well as, that there is low availability of essential medicines in public health units [138]. Because the list is not even in use in most LatAm countries, investigators are encouraged to verify if the essential drug list is up to date and to validate the list prior to implementing any DUR studies.

In relation to scientific information from DUR, the LatAm region faces particular challenges because of the low investment in research and development compared to developed countries [139], limited institutional/organizational resources, language barriers, health education and illiteracy, and sparse and incomplete data sources. There has also been limited training to perform critical appraisals of the literature, to adapt the results to local settings, and to provide continuing education programs for the application of results derived from DUR in policy and clinical decisionmaking. Despite a relative increase in the number of DUR studies conducted, there is clearly a need for additional support to publish study results, and for a multidisciplinary approach when developing interventions or educational programs in the region. Hopefully this will change as governments in the region recognize the need for DU studies to enhance their understanding of 
current drug utilization especially with the growing burden of NCDs and the implications on future medicine use.

\section{Future Direction}

In summary, the LatAm region faces particular challenges that might impact DUR. The challenges include high levels of socioeconomic inequality and high migration rates in some countries; high rates of violence, crime, trafficking and/or possession of drugs, existence of indigenous populations that have not reached overall living standards with low education, poor socioeconomic status, high medical needs with limited access to medicines; existence of multiple languages and native languages within the region that limits communication with high rates of unemployment, urban segregation, and low level of literacy mainly in rural and remote areas. In terms of DU studies, there are a number of issues and challenges that have been identified; however, their extent remains unknown at the country and regional level. These include: fragmentation of most healthcare systems; limited medical coverage in some areas and access to medicines; as well as sub-standard and counterfeit medicines and insufficient number of quality control centers for medicines. In addition, there are issues with appropriate use of medicines resulting in increased antimicrobial resistance, over-prescription of antimicrobials, use of inappropriate medicines among the elderly, polypharmacy, self-medication, and poor medication adherence in practice.

In terms of DUR per se, there is a low number of publications generated by local investigators, and some of those available have methodological issues such as lack of representativeness of the population, limited validation of DU data reported, and small sample size [140]. These issues might significantly impact clinical, regulatory and public health decision-making [ 141 ]. Longitudinal drug utilization studies to examine time trends in the utilization of drugs in the region are difficult to conduct because of frequently undocumented changes over time in legislation, reimbursement systems and market conditions. Because of the fragmented nature of the health care delivery system, and the problems with data keeping records and access to the data, it is often very difficult to respond to basic questions like the exposed population, i.e., who is getting what drug? at what time? All of those are core questions in drug utilization studies, and researchers in the field trying to find reliable and valid answers, are having difficulties to assess these in the current political and economic climate in Latin America.

In conclusion, DUR is an important discipline and the improvement of tools and resources in the LatAm region could help and facilitate a better understanding of the current state of DU and the health system in the region. Despite the identified challenges of DUR in the LatAm region, important measures could be put in place to strengthen regional DUR capabilities. The follow up publication in this series will outline potential solutions to overcome these challenges and provide some guidance for researchers interested in carrying out DUR in the region. Ultimately, improved DUR should inform effective policies which will promote the rational and efficient use of 
medication across LatAm, hopefully resulting in improved health outcomes for all patients in the region within available resources.

\section{References}

1 World Health Organization. Introduction to drug utilisation research, NLM classification WB 330. World Health Organization, Oslo. 2003. Available at: http://apps.who.int/medicinedocs/pdf/s4876e/s4876e.pdf. Accessed on March, 2018.

2 World Health Organization: The Pursuit of Responsible Use of Medicines. Sharing and Learning from Country Experiences. Technical Report prepared for the Ministers Summit. The benefits of responsible use of medicines: Setting policies for better and cost-effective health care. 2012. Available at:

http://apps.who.int/iris/bitstream/handle/10665/75828/WHO_EMP_MAR_2012.3_eng.pdf;jsessi onid=A7F8DE7B83D7B34F2816223604A8252A?sequence=1. Accessed on March, 2018.

3 Elseviers M, Wettermark B, Almarsdóttir AB, Andersen M, Benko R, Bennie M, et al. Drug Utilization Research: Methods and Applications. In: Wiley, editor. Drug Utilization Research: Methods and Applications, 2016.

$4 \quad$ Wettermark B, Vlahovic-Palcevski V, Salvesen Blix H, Rønning M, Vander Stichele RH. Drug utilization research. In: HartzemaAG, Tilson HH, Chan KA (eds) Pharmacoepidemiology and therapeutic risk assessment. Harwey Whitney Books, Cincinatti, 2008: 159-195.

5 Wettermark B. The intriguing future of pharmacoepidemiology. Eur J Clin Pharmacol. 2013;69 (Suppl 1):43-51.

6 Dos Santos JB, Almeida AM, Acurcio FA, de Oliveira Junior HA, Kakehasi AM, Guerra Junior AA, et al. Comparative effectiveness of adalimumab and etanercept for rheumatoid arthritis in the Brazilian Public Health System. Journal of comparative effectiveness research. 2016;5(6):539-49.

7 Godman B, Wettermark B, van Woerkom M, Fraeyman J, Alvarez-Madrazo S, Berg C, et al. Multiple policies to enhance prescribing efficiency for established medicines in Europe with a particular focus on demand-side measures: findings and future implications. Front Pharmacol. 2014;5:106.

8 Moon JC, Godman B, Petzold M, Alvarez-Madrazo S, Bennett K, Bishop I, et al. Different initiatives across Europe to enhance losartan utilization post generics: impact and implications. Front Pharmacol. 2014;5:219.

9 Eriksson I, Wettermark B, Bergfeldt K. Real-World Use and Outcomes of Olaparib: a Population-Based Cohort Study. Targeted oncology. 2018;13(6):725-33

10 Gram LE, Hallas J, Andersen M. Pharmacovigilance based on prescription databases. Pharmacol Toxicol. 2000;86 Suppl 1:13-5.

11 Pratt N, Roughead E. Assessment of Medication Safety Using Only Dispensing Data. Curr Epidemiol Rep. 2018;5(4):357-369.

12 Wettermark B, Persson ME, Wilking N, Kalin M, Korkmaz S, Hjemdahl P, et al. Forecasting drug utilization and expenditure in a metropolitan health region. BMC Health Serv Res. 2010;10:128.

13 Santa-Ana-Tellez Y, Mantel-Teeuwisse A, Leufkens H, Wirtz V. Seasonal variation in penicillin use in Mexico and Brazil: analysis of the impact of over-the-counter restrictions. Antimicrobial agents and chemotherapy. 2015;59(1):105-10.6-8. 
14 Kalungia AC, Burger J, Godman B, Costa JO, C S. Non-prescription sale and dispensing of antibiotics in community pharmacies in Zambia. Expert review of anti-infective therapy. 2016.

15 Kibuule D, Kagoya H, Godman B. Antibiotic use in acute respiratory infections in underfives in Uganda: findings and implications. Expert review of anti-infective therapy; 2016;14(9):863-72.

16 Holloway K, van Dijk L. Rational use of medicines. Chapter in: The world medicines situation 2011, 3rd ed. Geneva, World Health Organization, 2011. Available at: http://who.int/medicines/areas/policy/world_medicines_situation/en/index.html or http://apps.who.int/medicinedocs/documents/s20054en/s20054en.pdf?ua=1. Accessed on March, 2018.

17 Gomes RM, Guerra Junior AA, Lemos LL, Costa Jde O, Almeida AM, Alvares J, et al. Ten-year kidney transplant survival of cyclosporine- or tacrolimus-treated patients in Brazil. Expert Rev Clin Pharmacol. 2016 Jul;9(7):991-9.

18 Gattás VL, Braga PE, Koike ME, Lucchesi MBB, Oliveira MMM, Piorelli RO, Queiroz $\mathrm{V}$, Precioso AR. Safety assessment of seasonal trivalent influenza vaccine produced by Instituto Butantan from 2013 to 2017. Rev Inst Med Trop Sao Paulo. 2018 Dec 20;61:e4.

19 Cameron A, Ewen M, Ross-Degnan D, Ball D, Laing R. Medicine prices, availability, and affordability in 36 developing and middle-income countries: a secondary analysis. Lancet. 2009;373(9659):240-9.

20 Katende-Kyenda NL, Lubbe MS, Serfontein JH, Truter I. Inappropriateness of antimicrobial prescription in private primary health care settings in South Africa. S Afr Med J 2006;96(8):704-5

21 Lee D. Drug utilization in Panama. J Clin Epidemiol 1991; 44:31S-38S.

22 Yamey G. What are the barriers to scaling up health interventions in low and middle income countries? A qualitative study of academic leaders in implementation science. Globalization and Health. 2012;8(1):11.

23 Dean L, Gregorius S, Bates I, Pulford J. Advancing the science of health research capacity strengthening in low-income and middle-income countries: a scoping review of the published literature, 2000-2016. BMJ open. 2017;7(12):e018718.

24 Bigdeli M, Javadi D, Hoebert J, Laing R, Ranson K. Health policy and systems research in access to medicines: a prioritized agenda for low- and middle-income countries. Health Res Policy Syst. 2013;11:37.

25 Faleta J, McDade S, R. A. United Nations Development Programme (UNDP) in Latin America and the Caribbean. A partner for sustainable development. United Nations Report New York, NY. 2015.

26 Buschiazzo H, Chaves A, Figueras A, Laporte JR. Drug utilization in Latin America - the example of DURG-LA, Essential Drugs Monitor, 2003; 032.

27 Moscou K, Kohler JC, MaGahan A. Governance and pharmacovigilance in Brazil: a scoping review. J Pharm Policy Pract. 2016; 9: 3.

28 Drug Utilization Research Group, Latin America. Multicenter study on self-medication and self-prescription in six Latin American countries. Clinical Pharmacology and Therapeutics 1997;61:488-493.

29 Massele A, Burger J, Kalemeera F, Jande M, Didimalang T, Kalungia AC, Matshotyana K, Law M, Malone B, Ogunleye O, Oluka M, Paramadhas BD, Rwegerera G, Zinyowera S, Godman B. Outcome of the second Medicines Utilisation Research in Africa Group meeting to 
promote sustainable and appropriate medicine use in Africa. Expert Rev Pharmacoecon Outcomes Res. 2017 Apr;17(2):149-152.

30 Uppsala Monitoring Center. Available at https://www.who-umc.org/. Accessed on March 2018.

31 World Health Organization. Available at http://www.who.int/collaboratingcentres/en/. Accessed on March 2018.

32 United Nations, Department of Economic and Social Affairs, Population Division (2017).

World Population Prospects: The 2017 Revision, Key Findings and Advance Tables. ESA/P/WP/248. https://population.un.org/wpp/Publications/Files/WPP2017_KeyFindings.pdf

33 Barreto SM, Miranda JJ, Figueroa JP, Schmidt MI, Munoz S, Kuri-Morales PP, Silva JB Jr. Epidemiology in Latin America and the Caribbean: current situation and challenges. Int J Epidemiol. 2012 Apr;41(2):557-71.

34 United Nations Development Program. Regional Bureau for Latin America and the Caribbean. 2015, Published by the Bureau for Latin America and the Caribbean United Nations Development Programme. One United Nations Plaza, 22nd floor New York, NY 10017. http://www.latinamerica.undp.org/

35 Programa de las Naciones Unidas para el Desarrollo. Regional Human Development Report for Latin America and Caribbean 2010: Acting on the Future Breaking the Intergenerational Transmission of Inequality. 1st edn. San Jose', CR: Programa de las Naciones Unidas para el Desarrollo (PNUD), 2010, p. 208.

36 Belizán JM, Cafferata ML, Belizán M, Althabe F. Health inequality in Latin America. Lancet. 2007;370:1599-600.

37 Lopez H, Maloney W. Poverty Reduction and Growth-Virtuous and Vicious Circles. Washington DC: The World Bank; 2006.

38 Montenegro RA, Stephens C. Indigenous health in Latin America and the Caribbean. Lancet, 2006;367:1859-69.

39 United Nations Development Programme. Regional Human Development Report for Latin America and the Caribbean. Multidimensional progress: well-being. 2016.

http://www.latinamerica.undp.org/content/rblac/en/home/library/human_development/informeregional-sobre-desarrollo-humano-para-america-latina-y-e/

40 Comision Economica para America Latina y el Caribe. Poverty in Latin America. January 2019. https://www.cepal.org/en/pressreleases/poverty-latin-america-remained-steady2017-extreme-poverty-increased-highest-level. Accessed on April 1, 2019.

41 Gray Molina G, Abud MJ, Gomez Arteaga N, Gonzalez A, Ortiz-Juárez E, Sagredo J, Vasquez J. Human Development Report for Latin America and the Carribbean 2016. Progreso multidimensional: bienestar más allá del ingreso. United Nations Development Programme. Human Development Reports. http://hdr.undp.org/en/content/human-development-report-latinamerica-and-carribbean-2016. Accessed on June 2017.

42 United Nations Development Program. Human Development Report for Latin America 2013-2014: Citizen Security with a Human Face. Evidence and Proposals for Latin America. http://www.undp.org/content/undp/en/home/librarypage/hdr/humandevelopment-report-for-latin-america-2013-2014.html

43 Briceno-Leon R, Villaveces A, Concha-Eastman A. Understanding the uneven distribution of the incidence of homicide in Latin America. Int J Epidemiol 2008; 37:751-57. 44 Briceno-Leon R, Zubillaga V. Violence and globalization in Latin America. Curr Sociol 2002;50:19-37. 
45 UNODC Global Study on Homicide 2013. United Nations publication, Sales No.

14.IV.1. https://www.unodc.org/documents/data-and-

analysis/statistics/GSH2013/2014_GLOBAL_HOMICIDE_BOOK_web.pdf. Accessed on April 3, 2019.

46 Bhalla K, Harrison JE, Shahraz S, Fingerhut LA. Global burden of disease injury expert group. Availability and quality of cause-of-death data for estimating the global burden of injuries. Bull World Health Organ 2010; 88:831-38C.

47 Barreto, et al. Belizan JM, Cafferata ML, Belizan M, Althabe F. Health inequality in Latin America. Lancet 2007;370:1599-600.

48 Omran AR. The epidemiologic transition: a theory of the epidemiology of population change. Milbank Quarterly 2005;83(4):731-757.

49 Organizacion Panamericana de la Salud (OPS). Salud en las Americas. Panorama regional y perfiles del pais. Washington, DC, 2012. http://www.paho.org/salud-en-las-americas2017/?p=1457. Accessed on Sep 1, 2017

50 Rivera-Andrade A, Luna MA. Trends and heterogeneity of cardiovascular disease and risk factors across Latin American and Caribbean countries. Progress in Cardiovascular Diseases 2014;57(3):276-285.

51 Economic Commission for Latin America and the Caribbean. Mortality in Latin America: a favourable but heterogeneous trend. Santiago: UN ECLAC; 2007:27-43. Available from: http://www.cepal.org/publicaciones/xml/9/33269/od-4-mortalityinla.pdf.

52 Gawryszewski VP, Souza Mde F. Mortality due to cardiovascular diseases in the Americas by region, 2000-2009. Sao Paulo Medical Journal 2014;132(2):105-110.

53 Ordunez P, Prieto-Lara E, Pinheiro Gawryszewski V, Hennis AJ, Cooper RS. Premature mortality from cardiovascular disease in the Americas - Will the goal of a decline of " $25 \%$ by 2025" be met? PLoS ONE 2015;10(10):e0141685.

54 Organizacion Panamericana de la Salud (OPS). Documento base para el estudio del impacto de la exclusion de la atencion de salud sobre el acceso a medicamentos en Honduras, Guatemala y Nicaragua Washington, DCX, OPS, 2007.

55 Acunna C, Marin N, Mendoza A, et al. Determinantes sociales de la exclusion a los servicios de salud y a medicamentos en tres paises de America Central. Rev Panam Salud Publica, 2014;35 (2): 128-135.

56 Atun R, de Andrade LO, Almeida G, Cotlear D, Dmytraczenko T, Frenz P, et al. Healthsystem reform and universal health coverage in Latin America. Lancet (London, England). 2015;385(9974):1230-47.

57 Luiza, Vera Lucia et al. Catastrophic expenditure on medicines in Brazil. Rev. Saúde Pública [online]. 2016, vol.50, suppl.2, 15s.

58 Knaul FM, Wong R, Arreola-Ornelas H, Mendez O. Household catastrophic health expenditures: a comparative analysis of twelve Latin American and Caribbean Countries. Salud publica de Mexico. 2011;53 Suppl 2:s85-95.

59 World Health Organization. The World Health Report—-health systems financing: the path to universal coverage. Geneva: World Health Organization, 2010. http:/www.who.int/whr/2010/en/index.html (accessed May 27, 2017).

60 Escobar M-L, Griffi n CC, Shaw RP, eds. The impact of health insurance on low- and middle-income countries. Washington, DC: The Brookings Institution Press, 2011.

61 Canadian Institute for Health Information. National Health Expenditure Trends, 1975 to 2016. Ottawa, ON: CIHI; 2016. 
62 Lu Y, Hernandez P, Abegunde D. The world medicines situation 2011: Medicine expenditures; WHO, Geneva, Available at http://www.who.int/healthaccounts/documentation/world_medicine_situation.pdf, Accessed on March, 2018.

63 Almeida C. Health systems reform and equity in Latin America and the Caribbean: lessons from the 1980s and 1990s. Cad Saude Publica 2002;18:905-25.

64 Barbosa WB, Costa JO, de Lemos LLP, Gomes RM, de Oliveira HN, Ruas CM, et al. Costs in the Treatment of Schizophrenia in Adults Receiving Atypical Antipsychotics: An 11Year Cohort in Brazil. Applied health economics and health policy. 2018;16(5):697-709. 65 Godoi IP, Da Silva LVD, Sarker AR, Megiddo I, Morton A, Godman B, et al. Economic and epidemiological impact of dengue illness over 16 years from a public health system perspective in Brazil to inform future health policies including the adoption of a dengue vaccine. Expert review of vaccines. 2018;17(12):1123-33.

66 Marra LP, Araujo VE, Oliveira GC, Diniz LM, Guerra Junior AA, Acurcio FA, et al. The clinical effectiveness of insulin glargine in patients with Type I diabetes in Brazil: findings and implications. Journal of comparative effectiveness research. 2017;6(6):519-27.

67 Maia Diniz I, Guerra AAJ, Lovato Pires de Lemos L, Souza KM, Godman B, Bennie M, et al. The long-term costs for treating multiple sclerosis in a 16-year retrospective cohort study in Brazil. PloS one. 2018;13(6):e0199446.

68 Emmerick ICM, Luiza VL, Camacho LAB et al. Access to medicines for acute illness in middle income countries in Central America. Rev Saude Publica 2013;47(6):1069-1079.

69 World Health Organization. World Health Organization Fact Sheet 275. Revised 2006 February. http://www.who.int/mediacentre/factsheets/fs275/en/ (accessed June 2017).

70 Tadeg H, Berhane Y. Substandard and counterfeit antimicrobials: recent trends and implications to key public health interventions in developing countries. East Afr J Public Health. 2012 Jun;9(2):85-9.

71 World Health Organization. Growing threat from counterfeit medicines Bulletin of the World Health Organization, 2010; 88 (4): 241-320.

72 World Health Organization Fact Sheet 275. Available from:

http://www.who.int/mediacentre/factsheets/fs275/en/, Accessed on March 2018.

73 Green MD. Antimalarial drug resistance and the importance of drug quality monitoring. J Postgrad Med 2006;52:288-90.

74 Gautam CS1, Utreja A, Singal GL. Spurious and counterfeit drugs: a growing industry in the developing world. Postgrad Med J. 2009 May;85(1003):251-6.

75 Anvisa, Resolution RDC 81/2008. http://portal.anvisa.gov.br/resultado-de-

busca?_3_keywords=counterfeiting\&_3_formDate $=1441824476958 \& p \_p \_i d=3 \& p \_p \_l i f e c y c l e=$ $0 \& p \_p \_s t a t e=$ normal $\& p \_p \_$mode $=$view $\& \_3 \_$groupId $=0 \& \_3$ struts_action $=\% 2 F$ search $\% 2 F$ searc 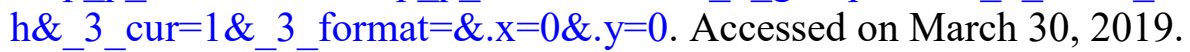

76 Lopes HR, Carvalho MC. Medicamentos falsificados e contrabandeados no Brasil:

panorama geral e perspectivas de combate ao seu consume.

https:/www.scielosp.org/article/csp/2014.v30n4/891-895/, 2014. Accessed on March 30, 2019.

77 Almuzaini T1, Choonara I, Sammons H. Substandard and counterfeit medicines: a

systematic review of the literature. BMJ Open. 2013 Aug 17;3(8):e002923.

78 Torloni MR, Gomes Freitas C, Kartoglu UH, Metin Gülmezoglu A, Widmer M. Quality of oxytocin available in low- and middle-income countries: a systematic review of the literature. BJOG. 2016 Dec;123(13):2076-2086. 
79 Dirección General de Medicamentos, Insumos y Drogas (DIGEMID), Centro Nacional de Control de Calidad del Instituto Nacional de Salud (CNCC-INS), Programa de Información y Calidad de Medicamentos de la Farmacopea de los Estados Unidos de América (USP DQI). Iniciativa de Enfermedades Infecciosas en América del Sur. Resumen del Segundo Estudio para Determinar la Calidad de Antimicrobianos y Antituberculosos Utilizados en la Red BEPECA de la Dirección de Salud Callao. Dirección de Salud Callao (DISA Callao). Junio 2009. http://apps.usp.org/app/worldwide/medQualityDatabase/download.php?id=10.

80 USAID-USP Promoting the Quality of Medicines (PQM) program, 2011.

http://www.usp.org/global/global-activities/latin-americacaribbean/government-and-institutionalactivities.

81 United States Food and Drug Administration. U.S. Department of Health and Human Services. Counterfeit Drug Task Force Interim Report. Rockville, Md.: U.S. Food and Drug Administration; 2003. Available at:

www.fda.gov/oc/initiatives/counterfeit/report/interim_report.html. Accessed May, 2017.

82 Duarte-Raya F, Granados-Ramírez MP. Resistencia antimicrobiana de bacterias en un hospital de tercer nivel. Rev Med Inst Mex Seguro Soc. 2012;50(3):289-300.

83 Kimball E. Latin America's growing pharma industry, 2013. Thomson Reuters. www.chemanager-online.com. Accessed May 2, 2017.

84 Salas M, Amato MJD, Martinez Cairo-Cueto S. Analysis of research studies during the regional meetings from the Mexican Social Security Institute. Revista Mexicana del Instituto Mexicano del Seguro Social (Mex) 1993;31(2):131-134.

85 Schmidt C, Clinical Research in Brazil - PLS 200/15, proceedings from "Accelerating Clinical Research in Brazil" seminar, 15 May 2017.

86 Dobrzanski W, Calmaggi A. Latin America: Challenges \& Opportunities in Clinical Research, Medpace.

87 Drummond M, Augustovski F, Kalo Z, Yang BM, Pichon-Riviere A, Bae EY, et al. Challenges faced in transferring economic evaluations to middle income countries. International journal of technology assessment in health care. 2015;31(6):442-8.

88 Pichon-Riviere A, Augustovski F, Garcia Marti S, Sullivan SD, Drummond M.

Transferability of health technology assessment reports in Latin America: an exploratory survey of researchers and decision makers. International journal of technology assessment in health care. 2012;28(2):180-6.

89 Perez-Gomez A, Mejia-Trujillo J, Brown EC, Eisenberg N. Adaptation and Implementation of a Science-Based Prevention System in Colombia: Challenges and Achievements. Journal of community psychology. 2016;44(4):538-45.

90 Homedes N1, Ugalde A, Forns JR. The World Bank, pharmaceutical policies, and health reforms in Latin America. Int J Health Serv. 2005;35(4):691-717.

91 Arrais, PSD, Fernandes, MEP, Pizzol TdSD, et al. Prevalence of self-medication in Brazil and associated factors. Rev. Saúde Pública, 2016; 50 suppl.2.

http://www.scielo.br/pdf/rsp/v50s2/0034-8910-rsp-s2-S01518-87872016050006117.pdf

92 Baldoni AdO, Ayres LR, Martinez EZ, Dewulf NdLS, Santos Vd, Obreli-Neto PR, et al. Pharmacoepidemiological profile and polypharmacy indicators in elderly outpatients. Brazilian Journal of Pharmaceutical Sciences. 2013;49: 443-52.

93 Reis AMM, Figueras A. Analysis of the evidence of efficacy and safety of over-thecounter cough medications registered in Brazil. Brazilian Journal of Pharmaceutical Sciences. 2010;46: 135-45. 
94 Del Fiol Fde S, Lopes LC, Barberato-Filho S, Motta Cde C. Evaluation of the prescription and use of antibiotics in Brazilian children. The Brazilian journal of infectious diseases: an official publication of the Brazilian Society of Infectious Diseases. 2013;17(3):3327.

95 Lopes LC, Silveira MS, Camargo IA, Barberato-Filho S, Del Fiol Fde S, Osorio-deCastro CG. Biological drugs for the treatment of psoriasis in a public health system. Revista de saude publica. 2014;48(4):651-61.

96 Ferreira TR, Lopes LC. Analysis of analgesic, antipyretic, and nonsteroidal antiinflammatory drug use in pediatric prescriptions. Jornal de pediatria. 2016;92(1):81-7.

97 Machado-Alba JE, Calvo-Torres LF, Garcia-Betancur S, Aguirre-Novoa A, BanolGiraldo AM. Drug utilisation study in patients receiving antiepileptic drugs in Colombia. Neurologia (Barcelona, Spain). 2016;31(2):89-96.

98 Villalobos AP, Barrero LI, Rivera SM, Ovalle MV, Valera D. [Surveillance of healthcare associated infections, bacterial resistance and antibiotic consumption in high-complexity hospitals in Colombia, 2011]. Biomedica: revista del Instituto Nacional de Salud. 2014;34 Suppl 1:67-80.

99 Rumman A, Candia R, Sam JJ, Croitoru K, Silverberg MS, Steinhart AH, et al. Public versus Private Drug Insurance and Outcomes of Patients Requiring Biologic Therapies for Inflammatory Bowel Disease. Canadian journal of gastroenterology \& hepatology. 2017;2017: 7365937.

100 Dominguez I, Rosales R, Cabello A, Bavestrello L, Labarca J. [Evaluation of antimicrobial consumption en 15 Chilean hospitals: Results of a collaborative work, 2013]. Revista chilena de infectología: órgano oficial de la Sociedad Chilena de Infectologia. 2016;33(3):307-12.

101 Zaidi M, Sifuentes-Osornio J, Rolón AL, Vázquez G, Rosado R, Sánchez M, et al. Inadequate therapy and antibiotic resistance. Risk factors for mortality in the intensive care unit. Arch Med Res. 2002;33(3):290-4.

102 Salas A, Aranda E. Antibiotic prescribing patterns as empirical therapy among hospitalized patients in a Bolivian paediatric teaching hospital. Acta Paediatr. 2007;96(10):15335.

103 Velázquez-Meza ME, Aires de Sousa M, Echaniz-Avilez G, Solórzano-Santos F, Miranda-Novales G, Silva-Sanchez J, et al. Surveillance of methicillin-resistant Staphylococcus aureus in a pediatric hospital in Mexico City during a 7-year period (1997 to 2003): clonal evolution and impact of infection control. J Clin Microbiol. 2004;42(8):3877-80.

104 Salas M, Amancio O, Prado R, Zapote F, Castro G, Higuera F, Rojas JA. Antiparasitic drugs in hospitalized patients. Revista de la Asociacion Mexicana de Farmacologia (AMEFAR) 1985:109.

105 Silva J, Gatica R, Aguilar C, Becerra Z, Garza-Ramos U, Velázquez M, et al. Outbreak of infection with extended-spectrum beta-lactamase-producing Klebsiella pneumoniae in a Mexican hospital. J Clin Microbiol. 2001;39(9):3193-6.

106 Le Grand A, Hogerzeil HV, Haaijer-Ruskamp FM. Intervention research in rational use of drugs: a review. Health Policy and Planning. 1999;14(2):89-102.

107 Cassoni TC, Corona LP, Romano-Lieber NS, Secoli SR, Duarte YA, Lebrão ML. Use of potentially inappropriate medication by the elderly in São Paulo, Brazil: SABE Study. Cad Saude Publica. 2014 Aug;30(8):1708-20. 
108 Machado-Alba JE, Moncada JC, Moreno-Gutiérrez PA. Medication errors in outpatient care in Colombia, 2005-2013. Biomedica. 2016 Jun 3;36(2):251-7.

109 Doubova Dubova SV, Reyes-Morales H, Torres-Arreola Ldel P, Suárez-Ortega M. Potential drug-drug and drug-disease interactions in prescriptions for ambulatory patients over 50 years of age in family medicine clinics in Mexico City.BMC Health Serv Res. 2007 Sep 19;7:147.

110 Lemos LLP, Guerra Junior AA, Santos M, Magliano C, Diniz I, Souza K, et al. The Assessment for Disinvestment of Intramuscular Interferon Beta for Relapsing Remitting Multiple Sclerosis in Brazil. PharmacoEconomics, 2018;36(2):161-173.

111 Leite SN, Vieira M, Veber AP. [Drug utilization studies: a synthesis of articles published in Brazil and Latin America]. Cien Saude Colet. 2008 Apr;13 Suppl:793-802. [Article in Portuguese]

112 Caires de Souza AL, de Assis Acurcio F, Guerra Junior AA, Rezende Macedo do Nascimento RC, Godman B, Diniz LM. Insulin glargine in a Brazilian state: should the government disinvest? An assessment based on a systematic review. Applied health economics and health policy. 2014;12(1):19-32.

113 Diniz D, Machado TRdC, Penalva J. A judicialização da saúde no Distrito Federal, Brasil. Ciência \& Saúde Coletiva. 2014;19:591-8

114 Catanheide ID, Lisboa ES, Souza LEPFd. Características da judicialização do acesso a medicamentos no Brasil: uma revisão sistemática. Physis: Revista de Saúde Coletiva. 2016;26:1335-56.

115 Barroso L. Da falta de efetividade a judicializacao excessive: direito a saude, fornecimento gratuito de medicamentos e parametros para a atuacao judicial.. Revista Interesse Público. 2008;Available from: http://bd.tjmg.jus.br/jspui/bitstream/tjmg/516/1/D3v1882009.pdf.

116 Assis Leitão LC, da S. Simões MO, Oliveira Simões AE, Costa Alves B, Carvalho Barbosa I, Barreto Pinto ME. Judicialização da saúde na garantia do acesso ao medicamento. Revista de Salud Pública. 2014;16: 360-70.

117 Reveiz L, Chapman E, Torres R, Fitzgerald JF, Mendoza A, Bolis M, et al. Litigios por derecho a la salud en tres países de América Latina: revisión sistemática de la literatura. Revista Panamericana de Salud Pública. 2013;33: 213-22.

118 Menicucci T, Machado J. Judicialization of health policy in the definition of access to public goods: individual rights versus collective rights. Braz Polit Sci Rev. 2010;4(1):33-68.

119 Macedo EId, Lopes LC, Barberato-Filho S. Análise técnica para a tomada de decisão do fornecimento de medicamentos pela via judicial. Revista de Saúde Pública. 2011;45:706-13. 120 Lopes LC, Barberato-Filho S, Costa AC, Osorio-de-Castro CGS. Uso racional de medicamentos antineoplásicos e ações judiciais no Estado de São Paulo. Revista de Saúde Pública. 2010;44:620-8.

121 Vieira FS, Pepe VLE, Marques DC, Barberato-Filho S, Lopes LC. Assistência farmacêutica e ações judiciais: propostas para melhorar o acesso e o uso de medicamentos / Pharmaceutical services and judicial decisions: proposals to improve access and rational use of medicines. Rev adm saúde. 2010;12(47).

122 Pinzón-Flórez CE, Chapman E, Cubillos L, Reveiz L. Prioritization of strategies to approach the judicialization of health in Latin America and Caribean. Rev Saud Pub. 2016;50: 56-70

123 Franco-Giraldo Á. The latest reform of the Colombian healthcare-related social security system. Rev Salud Publica (Bogota). 2012 Oct;14(5):865-77. 
124 Laurell AC. Health reform in Mexico: the promotion of inequality. Int J Health Serv. 2001;31(2):291-321.

125 Roth-Deubel AN, Molina-Marín G. Public health stewardship and governance regarding the Colombian healthcare system, 2012-2013. Rev Salud Publica (Bogota). 2013 JanFeb;15(1):44-55.

126 World Health Organization. Antimicrobial resistance. Available at: http://www.who.int/whr/1996/media_centre/executive_summary1/en/index 5.html and http://www.who.int/mediacentre/factsheets/fs194/en/. Accessed on March 2018.

127 Andrade SS, Sader HS, Jones RN, Pereira AS, Pignatari AC, Gales AC. Increased resistance to first-line agents among bacterial pathogens isolated from urinary tract infections in Latin America: time for local guidelines? Mem Inst Oswaldo Cruz. 2006 Nov;101(7):741-8. 128 Mendes C1, Marin ME, Quiñones F, Sifuentes-Osornio J, Siller CC, Castanheira M, Zoccoli CM, López H, Súcari A, Rossi F, Angulo GB, Segura AJ, Starling C, Mimica I, Felmingham D. Antibacterial resistance of community-acquired respiratory tract pathogens recovered from patients in Latin America: results from the PROTEKT surveillance study (19992000). Braz J Infect Dis. 2003 Feb;7(1):44-61.

129 World Health Organization, WHO Model Lists of Essential Medicines, http://www.who.int/medicines/publications/essentialmedicines/en/, accessed on Dec 2017 130 WHO. World Health Organization. National Essential Medicines Lists (NEMLs) Repository. http://appswhoint/medicinedocs/static/PublicSubcollections/National-EssentialMedicines-Lists-NEMLs-Repository/indexhtml. 2017.

131 World Health Organization. Progress of WHO Member States in Developing National Drug Policies and in Revising Essential Drug Lists. WHO/DAP/98.7. WHO Action Programme on Essential Drugs, Geneva, 1998.

132 Yamauti SM, Bonfim JRdA, Barberato-Filho S, Lopes LC. Essencialidade e racionalidade da relação nacional de medicamentos essenciais do Brasil. Ciência \& Saúde Coletiva. 2017;22:975-86.

133 Magarinos-Torres R, Esher Â, Caetano R, Pepe VLE, Osorio-de-Castro CGS. Adesão às listas de medicamentos essenciais por médicos brasileiros em atuação no sistema único de saúde. Revista Brasileira de Educação Médica. 2014;38:323-30.

134 Coelho HLL, Rey LC, Medeiros MSGd, Barbosa RA, Fonseca SGdC, Costa PQd. Uma comparação crítica entre a Lista de Medicamentos Essenciais para Crianças da Organização Mundial de Saúde e a Relação Nacional de Medicamentos Essenciais (Rename). Jornal de pediatria. 2013;89:171-8.

135 Yamauti SM, Barberato-Filho S, Lopes LC. Elenco de medicamentos do Programa Farmácia Popular do Brasil e a Política de Nacional Assistência Farmacêutica. Cadernos de saude publica. 2015;31:1648-62.

136 Fulone I, Barberato-Filho S, dos Santos MF, Rossi Cde L, Guyatt G, Lopes LC. Essential psychiatric medicines: wrong selection, high consumption and social problems. BMC public health. 2016;16: 52.

137 da Silva T, Treviso DJ, Heineck I, et al. Adherence to essential medicines in cities from three Brazilian states. Cad. Saúde Pública, 2010; 26 (4). http://www.scielo.br/scielo.php?pid=S0102-311X2010000400024\&script=sci_arttext.

138 Alvares J, Guerra AAJ, Araujo VE, et al. Access to medicines by patients of the primary health care in the Brazilian Unified Health System. Rev. Saúde Pública, 2017; 51, supl.2. http://www.scielo.br/scielo.p hp?script=sci_arttext\&pid=S 0034-89102017000300318 
139 Christian Rolfo, Christian Caglevic, Denisse Bretel, David Hong, Luis E Raez, Andres F Cardona, Ana B Oton, Henry Gomez, Urania Dafni, Carlos Vallejos, Christoph Zielinski. Cancer clinical research in Latin America: current situation and opportunities. Expert opinion from the first ESMO workshop on clinical trials, Lima, 2015, ESMO Open 2016; 1(4): e000055, 17 June 2016.

140 Duran CE, Christiaens T, Acosta A, Vander Stichele R. Systematic review of crossnational drug utilization studies in Latin America: methods and comparability.

Pharmacoepidemiology and drug safety. 2016;25(1):16-25.

141 Ali AK. Methodological Challenges in Observational Research: A

Pharmacoepidemiological Perspective. British Journal of Pharmaceutical Research.

2013;3(2):161-75. 